\title{
Retracted: Elucidation of Genotypic Variability, Character Association, and Genetic Diversity for Stem Anatomy of Twelve Tossa Jute (Corchorus olitorius L.) Genotypes
}

\author{
BioMed Research International \\ Received 23 January 2021; Accepted 23 January 2021; Published 26 February 2021 \\ Copyright (c) 2021 BioMed Research International. This is an open access article distributed under the Creative Commons \\ Attribution License, which permits unrestricted use, distribution, and reproduction in any medium, provided the original work \\ is properly cited.
}

BioMed Research International has retracted the article titled "Elucidation of Genotypic Variability, Character Association, and Genetic Diversity for Stem Anatomy of Twelve Tossa Jute (Corchorus olitorius L.) Genotypes" [1], due to significant textual overlap with the author's previously published article [2]:

Additionally, many of the figures and tables appear to overlap in these two articles:

Table 1 [1] overlaps with Table 1 [2]

Figure 1 [1] overlaps with Figure 1 [2]

Figure 2(b) [1] overlaps with Figure 2 [2]

Figure 3 [1] overlaps with Figure 3 [2]

Figure 2(a) [1] overlaps with Table 6 [2]

Table 2b [1] overlaps with Table 2 [2]

Figure 4 [1] overlaps with Figure 4 [2]

Table 4 [1] overlaps with Table 3 [2]

Table 7 [1] overlaps with Table 9 [2]

The authors disagree with this retraction.

\section{References}

[1] M. M. Mukul, "Elucidation of Genotypic Variability, Character Association, and Genetic Diversity for Stem Anatomy of Twelve Tossa Jute (Corchorus olitorius L.) Genotypes," BioMed Research International, vol. 2020, Article ID 9424725, 16 pages, 2020.

[2] M. M. Mukul, N. Akter, M. G. Mostofa et al., "Analyses of Genetic Variability, Character Association, Heritability and Genetic Advance of Tossa Jute (Corchorus olitorius) Genotypes for Morphology \& Stem Anatomy," American Journal of BioScience, vol. 8, no. 4, pp. 99-112, 2020. 